\title{
PENINGKATAN AKTIVITAS PROSES PEMBELAJARAN MELALUI PENERAPAN MODEL PEMBELAJARAN INKUIRI TERBIMBING PADA MATERI SISTEM PERNAPASAN PADA MANUSIA
}

\author{
Viona Zulianda ${ }^{{ }^{*}}$, Sri Irawati ${ }^{1}$, Yennita ${ }^{1}$ \\ ${ }^{1}$ Program Studi Pendidikan Biologi, Fakultas Keguruan dan Ilmu Pendidikan, Universitas Bengkulu \\ Email: vionazuu@gmail.com
}

\begin{abstract}
Abstrak
Penelitian ini bertujuan untuk mendeskripsikan peningkatan aktivitas belajar peserta didik dan aktivitas

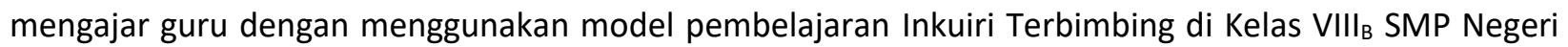
22 Kota Bengkulu. Jenis penelitian ini adalah Penelitian Tindakan Kelas dengan metode deskriptif. Penelitian ini terdiri dari dua siklus, masing-masing siklus terdiri dari 4 tahap yaitu: tahap perencanaan, pelaksanaan, pengamatan dan refleksi. Subjek penelitian ini adalah guru dan seluruh peserta didik kelas $\mathrm{VIII}_{B}$ SMP Negeri 22 Kota Bengkulu yang berjumlah 27 peserta didik. Instrumen penelitian yang digunakan adalah lembar observasi yang terdiri dari lembar observasi aktivitas guru dan aktivitas peserta didik. Hasil dari penelitian didapatkan data bahwa pada siklus I aktivitas mengajar guru diperoleh skor rata-rata yaitu 55 (Baik) dan pada siklus II skor aktivitas guru menjadi 58 (Baik). Pada siklus I aktivitas belajar peserta didik diperoleh skor rata-rata yaitu 55 (Baik) dan pada siklus II skor aktivitas belajar peserta didik menjadi 59 (Baik). Dari hasil penelitian dapat disimpulkan bahwa model pembelajaran Inkuiri Terbimbing dapat meningkatkan aktivitas mengajar guru dan aktivitas belajar peserta didik kelas VIII ${ }_{B}$ SMP Negeri 22 Kota Bengkulu.
\end{abstract}

Kata Kunci : Inkuiri Terbimbing, Aktivitas Peserta Didik, Aktivitas Mengajar Guru

\begin{abstract}
The purpose of the research to describe the increase in student learning activities and teacher teaching activities using a guided inquiry learning model in Class VIII ${ }_{B}$ of SMP Negeri 22 Kota Bengkulu. This type of research is Classroom Action Research with descriptive methods. This study consists of two cycles, each cycle consisting of four stages, namely: the stages of planning, implementation, observation and reflection. The subjects of this study were teachers and all class VIII ${ }_{B}$ students of SMP Negeri 22 Kota Bengkulu, amounting to 27 students. The research instrument used was an observation sheet consisting of observation sheets of teacher activities and activities of students. The results of the study obtained data that in the first cycle the teacher's teaching activities obtained an average score of 55 (Good) and in the second cycle the teacher activity score became 58 (Good). In the first cycle the learning activities of students obtained an average score of 55 (Good) and in the second cycle the score of learning activities of students became 59 (Good). From the results of the study it can be concluded that the guided inquiry learning model can improve teacher teaching activities and learning activities of class VIII $\mathrm{B}_{\mathrm{B}}$ students of SMP Negeri 22 Kota Bengkulu.
\end{abstract}

Keywords: Guided Inquiry, Student Activities, Teaching Activities Teacher

\section{PENDAHULUAN}

Pendidikan adalah modal utama bagi
suatu bangsa sebagai upaya untuk meningkatkan kualitas sumber daya manusia yang dimilikinya. Permasalahan utama didalam dunia pendidikan di Indonesia terutama berhubungan dengan mutu pendidikan, hampir semua bangsa berusaha meningkatkan kualitas 
pendidikannya karena pendidikan adalah modal utama bagi suatu bangsa sebagai upaya untuk meningkatkan sumber daya manusia yang dimilikinya (Mulyasa, 2015).

Upaya yang dilakukan untuk meningkatkan mutu pendidikan yang terbaik salah satunya yaitu peningkatan professional guru dan pengembangan kurikulum. Kurikulum 2013 lebih menekankan pada pelaksanaan proses pembelajaran. Proses pembelajaran harus benar-benar memperhatikan keterlibatan peserta didik, selama ini aktivitas pembelajaran di sekolah menengah belum optimal pada sifat kreatif dan antisipatif para guru sains dalam praktek pembelajaran untuk memaksimalkan peranan peserta didiknya, hal ini merupakan faktor penyebab rendahnya kualitas dan kuantitas proses dan produk pembelajaran sains (Arifah, 2012).

Aktivitas peserta didik adalah keterlibatan peserta didik dalam bentuk sikap, pikiran perhatian dan aktivitas dalam kegiatan pembelajaran guna menunjang keberhasilan proses belajar mengajar dan memperoleh manfaat dari kegiatan tersebut. Aktivitas belajar harus melibatkan seluruh aspek psikofisis dari peserta didik, baik jasmani maupun rohani sehingga perubahan perilakunya dapat terjadi secara cepat, tepat, mudah dan benar, baik pada aspek kognitif, efektif, dan psikomotorik. Aktivitas belajar juga dapat memberikan nilai tambah bagi peserta didik itu sendiri (Hanafiah, 2010).

Aktivitas mengajar guru adalah suatu kegiatan membimbing dan mengorganisasikan lingkungan sekitar anak didik dalam proses pembelajaran, agar tercipta lingkungan belajar yang kondusif yang memungkinkan terjadinya proses belajar yang optimal (Putra, 2013).
Sebagaimana berdasarkan wawancara guru Biologi kelas VIII ${ }_{B}$ SMPN 22 Kota Bengkulu tahun ajaran 2018/2019 pelaksanaan pembelajaran masih terdapat beberapa kendala dan masalah yaitu: 1) pesera didik kurang aktif dalam proses pembelajaran berlangsung; 2) peserta didik kurang berkerja sama dan kurang berpartisipasi di dalam kelompok diskusi; 3) guru belum optimal dalam menerapkan model-model pembelajaran yang inovatif yang berakibat pasifnya peserta didik dalam proses pembelajaran. Berdasarkan latar belakang diatas, maka peneliti dan guru biologi bekerja sama untuk melakukan perbaikan pembelajaran biologi di kelas VIII ${ }_{B}$ SMP Negeri 22 Kota Bengkulu dengan menerapkan model pembelajaran Inkuiri Terbimbing untuk meningkatkan aktivitas belajar peserta didik dan aktivitas mengajar guru.

Model pembelajaran Inkuiri

Terbimbing merupakan model pembelajaran yang melibatkan minat dan menantang peserta didik untuk menghubungkan dunia nyata dengan kurikulum. Model pembelajaran Inkuiri sering dianggap sebagai penemuan individu namun model pembelajaran Inkuiri ini merupakan model pembelajaran yang melibatkan kerja kolaboratif peserta didik sehingga masing - masing peserta didik dapat belajar dari yang lain dalam sebuah interaksi sosial yang kondusif (Jihad, 2012).

Pada proses Inkuiri Terbimbing permasalahan dalam penyelidikan diajukan oleh guru dan peserta didik untuk menentukan prosedur penyelidikan. Kemudian melaksanakan penyelidikan dan menganalisis data melalui diskusi yang dibimbing oleh guru menggunakan model pembelajaran Inkuiri Terbimbing dengan memberikan solusi terhadap masalah pembelajaran bagi peserta didik yang tidak 
terlalu aktif dan belum berpartisipasi di kelas dan menghadirkan pembelajaran yang membantu guru dalam meningkatkan pemahaman peserta didik terhadap konsep. Penelitian yang relevan oleh Sasmita (2017) menyatakan bahwa pembelajaran dengan menerapkan model pembelajaran Inkuiri Terbimbing dapat merangsang peserta didik agar lebih aktif dalam proses pembelajaran.

\section{METODE}

Jenis penelitian yang digunakan
dalam penelitian ini yaitu penelitian
tindakan kelas (Classrooom Action
Research). Metode penelitian yang
digunakan dalam penelitian ini adalah metode deskriptif. Subjek penelitian ini adalah guru dan seluruh peserta didik kelas VIIIB SMP N 22 Kota Bengkulu. Peserta didik berjumlah 27 orang terdiri dari 12 peserta didik perempuan dan 15 peserta didik lakilaki. Penelitian ini dilakukan pada semester genap tahun pelajaran 2018/2019 di kelas VIII $\mathrm{B}$ SMP N 22 Kota Bengkulu.

Teknik pengumpulan data pembelajaran yang digunakan dalam penelitian ini yaitu teknik observasi. Adapun instrumen yang digunakan dalam penelitian ini adalah lembar observasi aktivitas belajar peserta didik dan aktivitas mengajar guru. Lembar observasi aktivitas mengajar guru digunakan untuk mengobservasi aktivitas guru dalam mengajar dan membimbing peserta didik selama proses pembelajaran sesuai dengan sintaks pada model pembelajaran Inkuiri Terbimbing. Lembar observasi aktivitas peserta didik digunakan untuk mengobservasi aktivitas peserta didik selama proses pembelajaran sesuai dengan sintaks pada model pembelajaran Inkuiri Terbimbing.

Adapun teknik analisis data dalam penelitian ini menurut Arikunto (2010) dalam menganalisis data observasi dilakukan dengan cara berikut:

1) Rata-rata $=\frac{\text { jumlah skor yang diperoleh }}{\text { banyak observer }}$

2) Skor tertinggi = jumlah skor yang diamati $x$ skor tertinggi tiap aspek

3) Skor terendah = jumlah aspek yang diamati $x$ skor terendah tiap aspek

4) Selisih skor $=$ Skor tertinggi $\mathrm{x}$ skor terendah

5) Kisaran nilai : $\frac{\text { selisih skor }}{\text { jumlah kriteria penilaian }}$

(Arikunto, 2010).

Lembar observasi aktivitas mengajar guru dan aktivitas belajar peserta didik berjumlah 20 butir pengamatan, skor tertinggi tiap butir 3 dan skor terendah tiap butir 1, maka kategori penilaian untuk lembar observasi aktivitas guru dan aktivitas peserta didik dapat dilihat pada Tabel 1 :

Tabel 1. Interval Kategori Penilaian Lembar Observasi Aktivitas Guru dan Aktivitas Peserta Didik

\begin{tabular}{lcc}
\hline No & Interval & Interpretasi Penilaian \\
\hline 1 & $20-33$ & Kurang \\
2 & $34-46$ & Cukup \\
3 & $47-60$ & Baik \\
\hline
\end{tabular}




\section{HASIL DAN PEMBAHASAN}

Adapun hasil dari observasi aktivitas mengajar guru dan aktivitas peserta didik pada siklus I dan siklus II dapat dilihat pada Gambar 1:

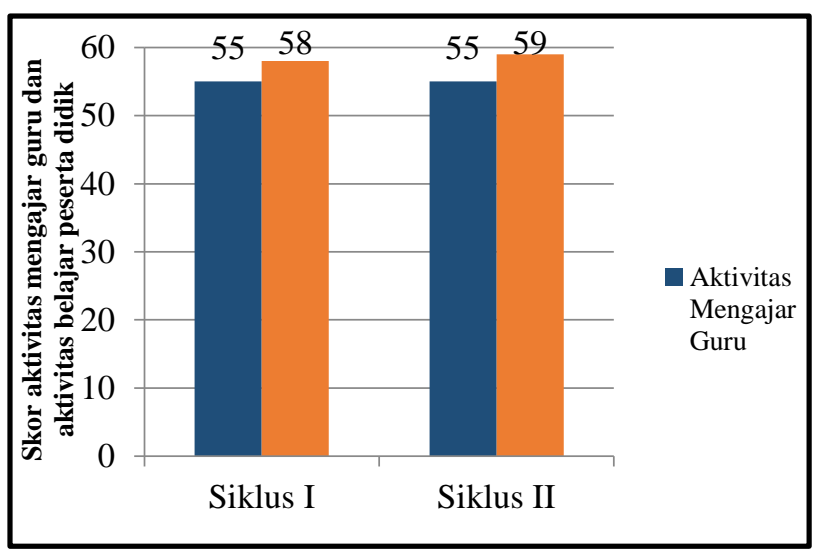

Gambar 1. Diagram aktivitas guru dan belajar peserta didik pada siklus I dan siklus II dengan penerapan model pembelajaran Inkuiri Terbimbing

Berdasarkan data hasil penelitian dari peningkatan aktivitas mengajar guru dalam proses pembelajaran Biologi pada materi sistem pernapasan pada manusia dengan menggunakan model pembelajaran Inkuiri Terbimbing (Guide Inquiry) menunjukan peningkatan dari siklus I ke siklus II, hal ini terlihat dengan peningkatan rata-rata skor dari observasi aktivitas mengajar guru pada siklus I mendapatkan skor 55 meningkat menjadi 58 di siklus II, yang artinya terjadi peningkatan pada aktivitas mengajar guru.

Hasil penelitian menunjukkan penerapan model pembelajaran Inkuiri Terbimbing untuk Mengembangkan Keterampilan Proses Sains Peserta Didik memberikan peningkatan aktivitas guru dan peserta didik dalam proses pembelajaran. Peningkatan aktivitas guru dan peserta didik terjadi karena adanya refleksi dari tiap sintaks model Inkuiri Terbimbing, Kegiatan di tiap sintaks inkuiri meliputi: orientasi, merumuskan masalah, merumuskan hipotesis, mengumpulkan data, menguji hipotesis, dan merumuskan kesimpulan. Aktivitas guru dan peserta didik menggunakan model Inkuiri Terbimbing dideskripsikan sebagai berikut:

\section{1) Orientasi}

Pada tahap orientasi kegiatan guru yaitu melakukan apersepsi, memotivasi dan menyampaikan tujuan pembelajaran. Apersepsi adalah kegiatan guru menghubungkan materi pembelajaran sebelumnya dengan materi yang akan diajarkan Pada siklus II, materi pembelajaran yaitu gangguan sistem pernapasan pada manusia. Pada siklus II guru melakukan apersepsi dengan mengajukan pertanyaan seperti: "apakah kalian pernah melihat orang merokok?" Peserta didik menjawab "pernah". Guru mengajukan pertanyaan lanjutan seperti: "bisakah kalian bayangkan bagaimana bentuk paru-paru orang yang merokok?". Pernahkah kalian melihat iklan-iklan tentang bahaya merokok terhadap sistem pernapasan manusia yang ada di televisi. Selanjutnya guru memotivasi peserta didik dengan menampilkan video terkait tentang bahaya merokok pada sistem pernapasan manusia. Penelitian Setiowati (2015), yang juga menayangkan video dan gambar terkait dengan materi pembelajaran pada aspek orientasi berguna untuk menyaring informasi-informasi tentang materi yang diajarkan.

Motivasi diberikan oleh guru melalui video dinilai baik walaupun pada tahap motivasi guru hanya memberikan sebuah video yang berkaitan dengan materi tanpa melengkapi dengan gambar sistem pernapasan pada manusia. Video yang ditampilkan guru sudah menarik, sesuai 
dengan materi dan tujuan pembelajaran. Hal ini sangat baik dilakukan untuk meningkatkan motivasi dan semangat belajar peserta didik sehingga proses pembelajaran dapat berjalan dengan baik dan optimal. Hal ini selaras dengan pendapat Mansur (2015), yang menyatakan bahwa motivasi adalah aspek yang sangat penting untuk membelajarkan peserta didik. Motivasi penting dilakukan untuk mengembangkan keterampilan proses sains peserta didik serta motivasi belajar peserta didik sehingga mendukung pencapaian hasil belajar yang maksimal. Hal ini sesuai dengan pernyataan Hosnan (2014) bahwa hasil belajar ditentukan oleh gabungan antara kemampuan dasar dan motivasi peserta didik.

Apabila terjadi penyimpangan tingkah laku yang mengganggu proses pembelajaran, guru hendaknya memberikan teguran dengan memerhatikan tegas dan jelas tertuju pada peserta didik yang mengganggu, dan Menghindari peringatan yang kasar, menyakitkan dan ejekan. Majid (2014) menyatakan bahwa pengelolaan kelas adalah keterampilan guru untuk menciptakan dan memelihara kondisi belajar yang optimal. Salah satu komponen keterampilan mengelola kelas yaitu menegur.

2) Merumuskan permasalahan

Hasil pengamatan aktivitas belajar peserta didik pada tahap rumusan masalah menurut pengamat I dan II di siklus I dan siklus II sudah berjalan baik. Menurut pengamat I dan pengamat II rumusan masalah pada siklus I dan siklus II yang disampaikan guru sudah sesuai dengan penyelidikan yang akan dilakukan dan sesuai dengan yang tertulis pada LKPD. Pada tahap merumuskan masalah, guru melakukannya dengan menayangkan suatu video serta menampilkan gambar tentang frekuensi pernapasan dan gangguan pernapasan pada manusia. Gambar dan video yang ditampilkan ini digunakan peserta didik untuk menjaring informasi terkait dengan kegiatan pembelajaran yang nantinya dilakukan. Setelah itu guru mengarahkan peserta didik merumuskan permasalahan dalam kelompok dari gambar dan video yang ditampilkan.

Menurut Suyono (2014) tahapan pengumpulan data melatih peserta didik untuk menggunakan metode ilmiah dalam menyelesaikan masalah, sehingga tidak mudah percaya pada sesuatu yang belum pasti kebenarannya. Kemudian peserta didik didorong untuk mencari jawaban yang tepat selama proses pembelajaran. Hasil menunjukkan bahwa seluruh peserta didik sudah dapat merumuskan permasalahan yang diarahkan oleh guru dan adanya perkembangan dari siklus I ke silus II. Penelitian Sasmita (2017) juga menyimpulkan bahwa aspek dalam merumuskan masalah peserta didik meningkat dari siklus I ke siklus II dengan menerapkan model pembelajaran Inkuiri Terbimbing.

3) Merumuskan hipotesis

Tahap merumuskan hipotesis merupakan tahap yang berfungsi untuk merangsang peserta didik dalam berpikir dan menjawab permasalahan. Peserta didik menuliskan pendapat mereka berdasarkan pengetahuan awal yang mereka miliki. Jawaban tersebut bukan hanya pendapat biasa, namun pendapat yang bersifat logis dan dapat dibuktikan. Jawaban ini menjadi patokan peserta didik dalam melakukan percobaan atau pengamatan. Peserta didik harus membuktikan hipotesis yang mereka 
tulis berdasarkan data hasil percobaan atau pengamatan yang mereka peroleh. Hal ini selaras dengan Trianto (2014), yang menyatakan bahwa hipotesis adalah jawaban sementara atas pertanyaan atau solusi permasalahan yang bersifat rasional dan dapat diuji dengan data. Tahapan ini dilakukan sebelum peserta didik melakukan kegaiatan percobaan atau pengamatan. Pada tahap ini peserta didik akan dibimbing untuk membuat jawaban sementara terkait rumusan masalah yang terdapat LKPD.

Pada penelitian yang dilakukan terjadi peningkatan dan perkembangan pada aspek merumuskan hipotesis peserta didik dari siklus I ke siklus II. Hal ini selaras dengan penelitian yang dilakukan Elsje (2010) menyimpulkan bahwa pada aspek merumuskan hipotesis peserta didik adanya peningkatan dari siklus I ke siklus II dengan menerapkan model pembelajaran Inkuiri Terbimbing di kelas VII SMPN 6 Kota Samarinda.

4) Mengumpulkan data

Tahap mengumpulkan data dilakukan untuk memperoleh data yang berguna dalam hal menguji hipotesis yang telah mereka buat sebelumnya. Pada tahap ini peserta didik dibimbing untuk melakukan percobaan atau pengamatan, serta mencatat hasil pengamatan pada tabel yang telah disediakan pada LKPD.

Pada siklus I dan II, menurut pengamat I dan pengamat II, guru membimbing peserta didik untuk mengumpulkan data dengan tepat. Guru membimbing 5 kelompok dengan melakukan pengelolaan kelas untuk membagi perhatian dalam membimbing setiap kelompok. Guru juga mengarahkan peserta didik dalam mengumpulkan data. Hal ini sesuai dengan pernyataan dalam Suyono (2014) bahwa dalam persiapan pembelajaran, guru bertindak sebagai pengarah atau pengelola kegiatan dengan cara mengarahkan pengembangan rencana penyelidikan yang hendak dilakukan oleh peserta didik. Trianto (2014) menyatakan bahwa dalam pembelajaran Inkuiri, mengumpulkan data merupakan proses mental yang sangat penting dalam pengembangan intelektual. Tugas dan peran guru pada tahapan ini adalah mengajukan pertanyaan-pertanyaan yang dapat mendorong siswa untuk berpikir mencari informasi yang dibutuhkan.

5) Menguji hipotesis

Pada tahap pengujian hipotesis guru membimbing semua anggota kelompok menguji hipotesis berdasarkan data hasil pengamatan yang telah dilakukan. Tahap menguji hipotesis dilakukan guru dengan cara memberikan pertanyaan-pertanyaan tentang hasil percobaan, dan berkeliling untuk melihat hasil jawaban peserta didik serta bertanya kembali perihal pertanyaan yang telah dijawab peserta didik yang dianggap salah dan memberikan waktu untuk peserta didik mengubah jawaban yang salah tadi ke jawaban yang benar.

$$
\text { Tahap menguji hipotesis }
$$
merupakan tahap puncak dalam proses pembelajaran inkuiri. Dalam Permendikbud (2014) tahap pengujian hipotesis bertujuan agar proses belajar akan berjalan dengan baik dan kreatif untuk membuktikan suatu konsep, teori, aturan atau pemahaman melalui contoh-contoh yang dijumpai dalam kehidupannya. Pada tahap ini peserta didik akan membuktikan sendiri hipotesis yang mereka tulis, berdasarkan data-data yang mereka peroleh dari proses percobaan atau pengamatan yang telah dilakukan sebelumnya. Peserta didik akan membuktikan dan menemukan suatu konsep sendiri secara langsung dengan 
mencocokkan antara data yang mereka peroleh dengan hipotesis yang mereka buat sebelumnya. Hipotesis dianggap benar apabila sesuai dengan data yang telah dikumpulkan, namun hipotesis dianggap salah apabila tidak sesuai dengan data yang telah dikumpulkan.

Pada penelitian yang telah dilakukan didapatkan data bahwa aspek mengujui hipotesis peserta didik meningkat dari siklus I ke Siklus II. Penelitian Dewi (2013), juga menyimpulkan bahwa terjadinya peningkatan aktivitas dan sikap ilmiah peserta didik dengan menerapkan model pembelajaran Inkuiri Terbimbing dalam pembelajaran IPA.

6) Merumuskan kesimpulan

Hasil penelitian menunjukkan adanya peningkatan dari siklus I ke siklus II pada penelitian yang telah dilaksanakan dan aktivitas peserta didik mengalami peningkatan dari siklus I ke siklus II dalam proses pembelajaran. Proses dalam menyimpulkan pembelajaran merupakan proses akhir yang sangat penting dilakukan dalam proses pembelajaran untuk menguatkan informasi dan materi yang telah diperoleh dan dibuktikan sendiri dalam proses pembelajaran. Oleh karena itu, proses ini harus dilaksanakan dengan baik. Hal ini selaras dengan Majid (2014), yang menyatakan bahwa merumuskan kesimpulan merupakan tujuan utama dalam proses pembelajaran. Untuk mencapai kesimpulan yang akurat sebaiknya guru mampu menunjukkan pada peserta didik data yang benar dan relevan. Dimana dalam merumuskan kesimpulan harus sesuai dengan rumusan masalah dan tujuan yang diberikan. Hal ini sebagaimana pernyataan dalam Suprihatiningrum (2016) bahwa kesimpulan didapatkan berdasarkan tujuan pembelajaran.
Penelitian Ulansari (2017), juga menyimpulkan bahwa aktivitas peserta didik dan hasil belajar peserta didik dengan menggunakan model pembelajaran Inkuiri meningkat dari siklus I ke siklus II.

\section{PENUTUP}

\section{Simpulan}

Adapun kesimpulan dalam penelitian tindakan kelas ini adalah sebagai berikut: Pembelajaran biologi pada materi sistem pernapasan pada manusia dengan menerapkan model pembelajaran Inkuiri Terbimbing dapat meningkatkan aktivitas mengajar guru dan dan aktivitas belajar peserta didik kelas VIII ${ }_{B}$ SMP Negeri 22 Kota Bengkulu pada siklus I dengan rerata skor aktivitas mengajar guru dari 55 mengalami peningkatan disiklus II menjadi 58 dan rerata aktivitas peserta didik dari 55 menjadi 59.

\section{Saran}

Peneliti selanjutnya yang akan melakukan penelitian PTK menggunakan model pembelajaran Inkuiri Terbimbing (Guide Inquiry) untuk meningkatkan aktivitas belajar peserta didik hendaknya dapat lebih mengoptimalkan proses pembelajaran sesuai dengan sintaks Inkuiri Terbimbing dan mengetahui kemampuan awal peserta didik dan memanajemen waktu dengan sebaik mungkin sehingga penelitian tindakan dapat berjalan dengan optimal.

\section{DAFTAR PUSTAKA}

Arifah, dkk. 2012. Perencanaan dan Desain Sistem Pembelajaran. Jakarta: Kencana

Arikunto, S., Suhardjono, \& Supardi. (2009). Penelitian Tindakan Kelas. Jakarta: PT Bumi Aksara. 
Dewi, N.L. 2013. Pengaruh Model Pembelajaran Inkuiri Terbimbing Terhadap Sikap Ilmiah dan Hasil Belajar IPA. Jurnal pendidikan dasar Indonesia. 3 (1): 1-10. (online). http://oldpasca.undiksha.ac.id/ejournal/index.php/jurnal pendas/ar ticle/view/512, diakses tanggal 24 juli 2019

Elsje, T. 2010. meningkatkan kemampuan kerjasama belajar biologi melalui penerapan strategi Inkuiri Terbimbing pada peserta didikkelas VII SMP Negeri vi kota samarinda. Jurnal Universitas Mulawarman Kalimantan Timur. 2 (1): 1-13. (online).

http://ojs.fkip.ummetro.ac.id/index.php /biologi/article/view/197, diakses tanggal 25 juli 2019

Hanafiah, N., \& Suhana, C. 2010. Konsep strategi Pembelajaran. Bandung: PT Refika Aditama

Hosnan, M. 2014. Pendekatan Saintifik dan Kontekstual dalam Pembelajaran Abad 21. Bogor: Ghalia Indonesia.

Jihad, A., \& Haris, A. 2012. Evaluasi Pembelajaran. Yogayakarta: Multi Pressido

Majid, A. 2014. Strategi Pembelajaran. Bandung: PT Remaja Rosdakarya

Mansur. 2015. Menciptakan Pembelajaran Efektif Melalui Apersepsi. Sulawesi Selatan: Widyaiswara LPMP

Mulyasa. 2015. Pengembangan dan Implementasi Kurikulum 2013. Jakarta: PT Remaja Rosdakarya
Putra, S. R. 2013. Desain Belajar Mengajar Kreatif Berbasis Sains. Yogyakarta: Diva Press.

Peraturan Mendikbud Nomor 22 Tahun 2014. Tentang Standar Proses Pendidikan Dasar dan Menengah. Jakarta: Kementerian Pendidikan Dan Kebudayaan Republik Indonesia (Salinan)

Sasmita, P.R. 2017. Penerapan Metode Inkuiri Terbimbing Menggunakan Media KIT Fisika: Upaya Meningkatkan Aktivitas dan Hasil Belajar Fisika Siswa. Jurnal ilmiah pendidikan Fisika. 6 (1): 1-8. (online).

http://ejournal.radenintan.ac.id/i ndex.php/albiruni/article/view/59 9

Setiowati. H, ANC Saputro. 2015. Penerapan Model Pembelajaran Inkuiri Terbimbing dilengkapi LKS untuk meningkatkan aktivitas dan prestasi belajar siswa kelas XI MIA SMAN 1 Banyudono pada materi pokok kelarutan. Jurnal Pendidikan. 2(1): 112.(online),https://www.jurnal.fkip.un s.ac.id/index.php/kimia/article/downlo ad/6886/4833. Diakses tanggal 23 Juli 2019

Suprihatiningrum, Jamil. (2016). Strategi Pembelajaran. Jogjakarta: Ar-Ruzz Media

Suyono dan Hriyanto. 2014. Belajar dan Pembelajaran. Bandung: PT Remaja Rosdakarya Offset

Trianto. 2014. Mendesain Model Pembelajaran Inovatif, Progresif dan Kontekstual: Konsep, Landasan, dan Implementasinya pada Kurikulum 2013 (Kurikulum 
Tematik Integratif/KTI). Jakarta:

Prenadamedia Group

Ulansari, P.T. 2017. Penerapan Model Pembelajaran Inkuiri Untuk Meningkatkan Aktivitas dan Hasil Belajar Siswa. Diklabio: Jurnal Pendidikan dan Pembelajaran Biologi 